\title{
AMAZŌNIA BRASILEIRA Preâmbulo a uma Discussão Antropológica da Questão Indígena
}

\author{
Renate Brigitte Viertler (1)
}

\begin{abstract}
RESUMO: $O$ presente artigo tem como objetivo elaborar um quadro panorâmico dos principais processos sociais que ocorrem na Amazônia Brasileira. Este referencial é de grande importáncia para os etnólogos que estudam os pequenos segmentos da socieda. de amazónica, representados pelos remanescentes atuais de populaçōes indigenas. Obrigadas a se adaptarem a profundas transformaçôes das suas condiçỗes de sobrevivência. as tribos indigenas resistem, sem abrir máo de sua identidade étnica. Ao nivel da consciencia, os processos sociais emergem sob uma grande variedade de estereotipos que presidem o sentido das relações interétnicas.
\end{abstract}

\begin{abstract}
This artic/e intends to present an overview of the main social processes going on in Brazilian Amazonia. These processes must not be neglected by the ethnologists studying partly integrated brazilian Indian populations. Indian tribes have been obliged to adapt to strong changes of their general conditions of survival without giving up their ethnic identities. At the conscious level, these macro and micro-social processes emerge as various stereotypes emerging from interethnic inter-relationships.
\end{abstract}

\section{INTRODUC̣ĀO}

A experiência do trabalho de campo com os remanescentes das populações tribais indígenas do Brasil revela que, por mais mudados que nos apareçam à primeira vista, não podem ser considerados assimilados. Apesar de numerosas concessões, feitas principalmente na esfera de cultura material, da tecnologia, da indumentária, ou padrões alimentares, os grupos tribais brasileiros resistem como entidades étnicas indias muito diversificadas.

No caso do Brasil, a resistência indigena tem como fundamento um ethos guerreiro-caçador. Portanto, difere do sentido camponês que permeia a resistência indígena de áreas culturais hispano-americanas.

Em termos conceituais, a resistência indigena do índio brasileiro, por vezes, é concebida em termos da concepção de um campesinato indigena, proposta que ainda está por ser melhor aprofundada. 
Uma coisa é falar de um processo de acamponesamento do índio em função da sua adaptação às novas condições de sobrevivência, outra, a de considerá-lo como pertencente a uma cultura camponesa engendrando formas específicas de resistência cultural.

Lembremos que a história do Brasil, no seu -capítulo relativo à história das relações interétnicas, evidencia que grande número de tribos brasileiras chegou a prestar serviços de guerra ao civilizado dominador. Mercenários, bons conhecedores dos territórios interioranos e das técnicas de sinalização e guerras de emboscada, sabemos de grupos Mundurucu, Bororo, Kayapó que ajudavam na tarefa do massacre e do amansamento de comunidades indígenas hostis.

A resistência cultural das tribos brasileiras expressa-se por uma grande variedade de processos sócio-culturais que, no seu conjunto, levaram a

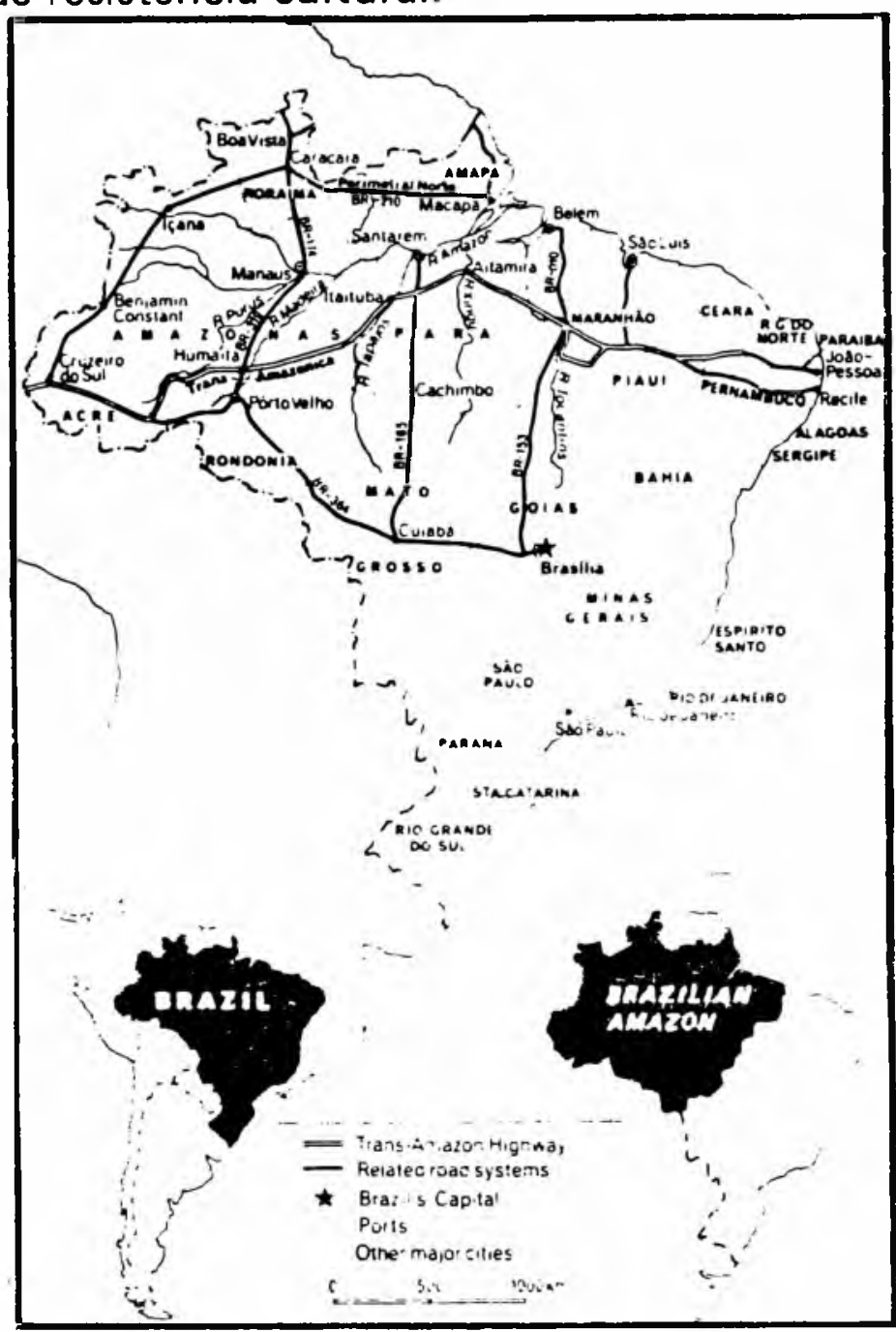

Fonte: DAVIS, S. Victims of the miracle. Development and the Indians of Brazil. Cambridge, Cambridge University Press, 1977.

um crescente enquistamento dos grupos indígenas, em resposta à expansão das frentes pioneiras brasileiras. Este enquistamento ou fechamento intensificou-se com a abertura desordenada do interior brasileiro, primeiro, pela ocupação do planalto central, com a transferência do Distrito Federal do Rio de Janeiro para Brasília, em Goiás; depois, pela política desenvolvimentista da Amazônia, num esforço econômico de grandes proporções realizado pelo governo brasileiro e grandes empresas nacionais e multinacionais ligadas à agropecuária, à mineração e à especulação de terra.

Dada a grande concentração de tribos indígenas atuais na área correspondente à Amazônia Legal, o quinhão da Amazônia que mais 


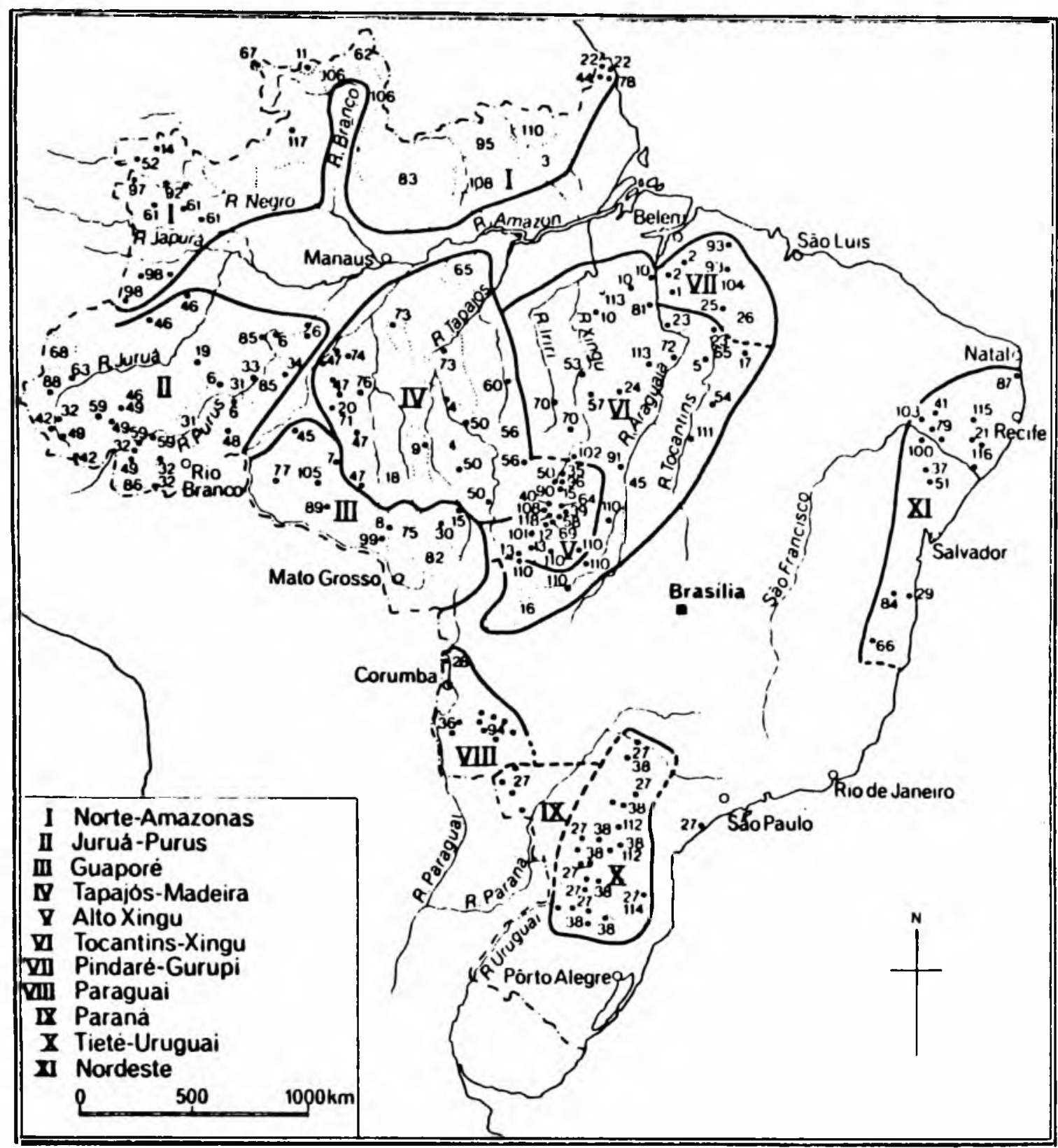

Fonte: DA.VIS, S. Victims of the miracle. Development and the Indians of Brazil. Cambridge, Cambridge University Press. 1977. p. 8-9.

interessa aos projetos governamentais, estas acabaram sofrendo os impactos deste processo por intermédio da invasão das suas terras tradicionalmente exploradas e da remoção forçada das próprias áreas de moradia.

Frente a estas pressões, as sociedades indígenas brasileiras desenvolveram vários processos de proteção e regeneração de suas próprias comunidades.

No caso dos índios Bororo do Mato Grosso, sociedade indígena que venho pesquisando desde 1970, a mágoa da perda de tantos pa- 
Map 2. Brazil: Indian groups and culture areas

Key 10 indigenous groups of Brazil:

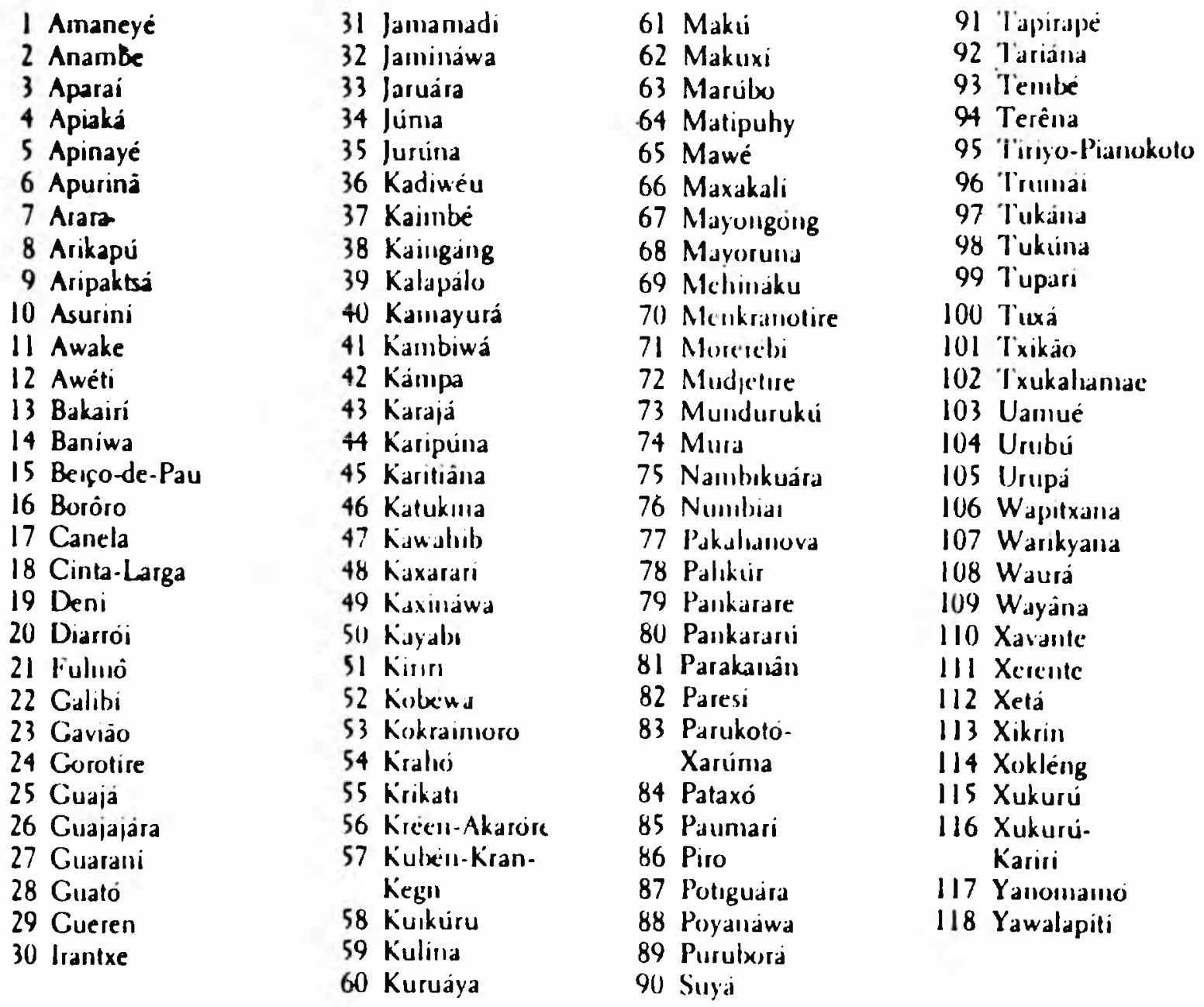

Source: "Indigenous Croups of Brazil," in W. Dustal (ed.), The Situation of the Indiun in South America (Geneva, 1972), pp. 434-42.

rentes, efeito do decréscimo populacional acarretado pela incidência de epidemias, faz com que associem o civilizado a um ser perigoso e impiedoso. Evitam-se casamentos mistos, principalmente entre homens Bororo e mulheres civilizadas; desprestigiam-se os Bororo que vivem como Barae ("civilizados") e que não sabem falar a língua dos antigos; retêm as prerrogativas cerimoniais (insígnias de prestígio, títulos de ancestrais, enfeites plumários tradicionais, conhecimento de cantos e mitos) nas mãos dos que vivem como Boe (Bororo verdadeiros); persistem em padrões de distribuição de alimentos e de outros 
recursos materiais segundo valores de uma economia tradicional; enganam e burlam o civilizado por ocasião das trocas interétnicas; realizam cerimônias funerárias congregando parentes de muitas aldeias, ocasiões em que os civilizados devem total submissão aos chefes cerimoniais Bororo; incutem nas crianças o medo do Baraedo; acham-se no direito de enganar os Barae, pois estes não cumpriram as suas promessas; e, segundo os mitos, arrependem-se de tê-los criado e de terem-se submetido a seres incontroláveis e desrespeitosos.

O Bororo quer as posses do civilizado, mas não quer ser civilizado. O Baraedo matou muitos Bororo por causa do "meriri" termo que significa metais preciosos, o que se explica pela história do contato interétnico iniciado por ocasião da exploração do ouro em Mato Grosso, em 1719. "Meriri" também significa dinheiro, remédio mágico que tudo pode. $E$ os Barae, juntamente com todos os seus bens o gado bovino, o cavalo, a galinha, o cachorro doméstico, a mandioca, a cana-de-açúcar, o dinheiro, a roupa, os utensílios de ferro - pertencem a um clã Bororo de pouco prestígio social já que, por sua imprevisibilidade, nem o Baraedo nem o "meriri" que ele tanto procura, podem ser vistos como garantias de benefícios para as comunidades. Em oposição, o prestígio ainda continua associado à generosidade e à partilha dos recursos materiais, decantadas pelas belas falas dos grandes homens.

Dada a virulência do processo de ocupação dos territórios indígenas por parte dos civilizados, aumenta o ritmo das transformações sofridas pelas sociedades indigenas. $O$ fato de estarem resistindo aos impactos provocados pela expansão da sociedade nacional brasileira não significa que deixem de arcar com graves custos ou dificuldades de reorganização da vida social em suas comunidades.

Torna-se urgente documentar estes processos com o maior rigor etnográfico, embora seja indispensável inserir esta Etnografia num quadro mais geral de processos que valeria a pena considerar no caso, algumas características dos processos sociais que afetam a Amazônia Brasileira, cuja compreensão não poderia prescindir de alguns marcos históricos relativos à sua ocupação.

Sabemos também que a Amazônia, além de índios, é ocupada por contingentes camponeses, igualmente submetidos ao impacto de processos de usurpação de terras, mas cuja adaptação se reflete num al to grau de dispersão territorial, ao contrário dos contingentes índios.

A condição jurídica do índio brasileiro, os projetos de desenvolvimento econômico afetando territórios indígenas, a representação 


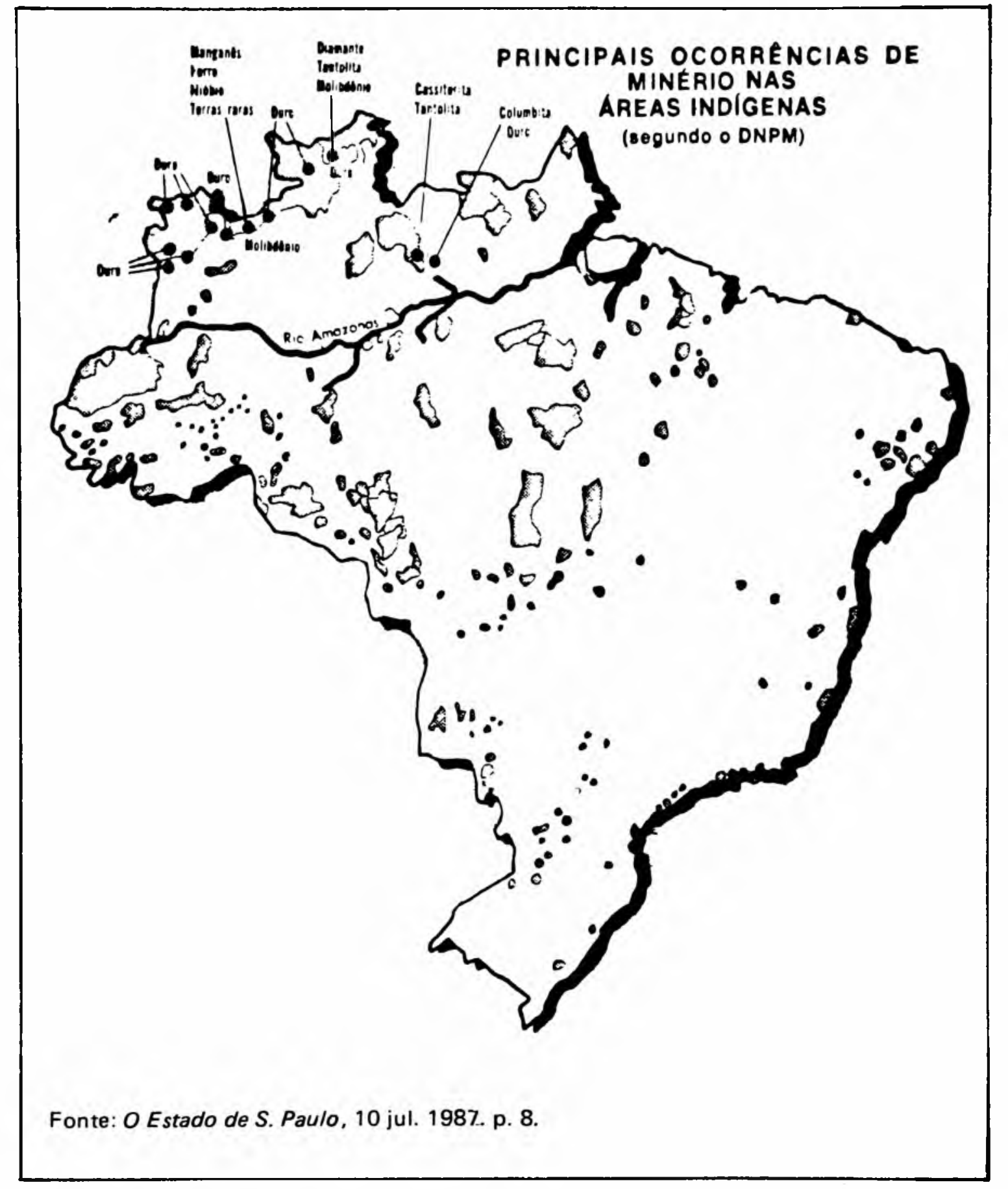

política do índio junto ao Estado brasileiro e demais questões correlatas só podem ser devidamente avaliadas quando inseridas no contexto dos complexos processos sociais que afetam a população brasileira. Delineá-los é tarefa por demais difícil, razão pela qual me contentarei em resgatar apenas alguns elementos históricos e sociológicos pertinentes à história da ocupação da Amazônia. Trabalho mais abrangente e profundo sobre o mesmo tema implicaria em uma síntese multi e interdisciplinar que ainda está por ser feita. 


\section{CARACTERISTICAS DOS PROCESSOS SOCIAIS}

- Delimitação e Características Geopolíticas da Amazônia

"A Bacia Amazônica é o maior sistema hidrográfico do planeta com uma área de 7 milhões de $\mathrm{km}^{2}$, que correspondem a 2/5 da América do Sul. Desse total, 4,8 milhões de $\mathrm{km}^{2}$ formam a Amazônia brasileira, área que corresponde a $69 \%$ do território do país. 0 perímetro da bacia amazônica abarca as regiões norte, noroeste e sudeste do continente, englobando, além do Brasil, grande parte da Venezuela, Colômbia, Equador, Peru e Bolívia. A Amazônia representa $1 / 5$ da disponibilidade mundial de água doce, $20 \%$ das reservas florestais do planeta e seu principal reservatório de oxigênio." (Almeida Mello, 1987)

"Comparativamente aos demais Estados condôminos, o Brasil ocupa uma posição geográfica privilegiada na Bacia Amazônica. O país tem $69 \%$ da área total, serve de recipiente para todas as suas águas, controla sua desembocadura no Atlântico e tem limites com os demais paises amazônicos, à exceção do Equador. Entretanto, embora represente 3/5 do território nacional, a Amazônia brasileira tem uma população inferior a 8 milhões de residentes (1986), dos quais $1 / 3$ estão concentrados em Belém e Manaus. O extrativismo e a agropecuária são as principais atividades econômicas da região. Os recursos minerais, ainda não totalmente pesquisados, são imensos (ao sul do Pará, a província mineral dos Carajás, a hidroelétrica de Tucuruí). com uma geopolítica interna de valorização do espaço amazônico se articula uma geopolítica externa de projeção continental que tem, como uma de suas metas, a presença brasileira no Caribe e no Pacífico." (Almeida Mello, 1987)

- A Ocupação da Amazônia: aspectos históricos

Num rápido retrocesso histórico, lembremos que a estrutura agrária brasileira sempre se baseou em grandes propriedades, primeiro, à base do trabalho escravo, preponderantemente negro, depois, com base no trabalho livre de imigrantes, mestiços, índios destribalizados e negros libertos. 
Para a Coroa Portuguesa, a Amazônia, além de uma vasta área propícia à indústria extrativa, representava uma via importante de acesso a remotas áreas interioranas, que cabia proteger de possiveis invasões por parte de representantes da América Espanhola. Por isto, erigiram-se fortes militares e missões religiosas que-não poderiam deixar de interferir sobre os padrões de ocupação territorial dos grupos indígenas da área. Estes, quando não eram dizimados ou demograficamente reduzidos por epidemias trazidas pelos colonizadores, acabavam por se submeter à catequese religiosa e laica, relocar suas comunidades, engajar-se como mão-de-obra em atividades de coleta e perder o controle de vastos territórios de exploração. $O$ desfecho do processo foi a sua crescente dependência econômica em relação ao branco e seu gradativo endividamento junto aos comerciantes, que Ihes traziam facas, roupas, sal, cachaça etc., em troca dos produtos coletados (1).

Se o período de 1600 a 1759 correspondeu à expansão portuguesa, a guerras, à catequese militar e religiosa dos indígenas da área, o compreendido entre 1759 e 1840 teve como características principais a expulsão dos jesuítas, a intensificação do extrativismo e a afirmação do poder secular comercial. A área era rica em madeiras, salsaparrilha, guaraná, poaia, caça e pesca, embora o cultivo fosse incipiente $(2)$

(1) Segundo Galvão, no século XVI, deu-se inicio a um processo de dizimação das populações indigenas ribeirinhas aos grandes rios da Amazônia, nas várzeas, ocupadas pelos portugueses. Seus remanescentes refugiaram-se em áreas mais inóspitas, as terras firmos, onde, por vezes, chegaram a confederar-se, formando novos aglomerados, contra o intruso civilizado, o que engendrou processos de readaptação recíproca e transculturaç̧̃o entre as culturas tribais de origens históricas, lingüisticas e geográficas muito diversas. Se, em 1900, o Brasil contava com uma população dividida em 230 grupos tribais, a intensificação dos contatos interétnicos e a perda dos territórios tribais chegou a reduzilos a 87 grupos, em 1950. Os indigenas de algumas regiôes tais como o rio Negro e o rio Içana revidaram a estas pressōes do civilizado organizando movimentos nativistas desde 1834 (Galvão, 1979, p.30).

(2) Em determinado momento da história de suas relações com o branco, os Mundurucu produziam a farinha de mandioca consumida pelos regionais não-indios que, sem condicões para fazerem suas próprias roças, obtinham alimento por meio da troca de instrumentos de ferro, artigos manufaturados e outros recursos muito apreciados por estes indios. Tais trocas propiciaram a crescente dependência e o endividamento comercial dos Mundurucu, atrelando-os inclusive às atividades de exploração da borracha. (Murphy. 1960). 
O apogeu do extrativismo deu-se com o boom da borracha, no período de 1840 a 1920, quando o trabalho da extração era realizado por algumas populações indígenas e contingentes de nordestinos advindos do Maranhão (Martins, 1981, p. 49). Os efeitos deste processo redundaram na inserção cada vez maior dos indígenas na teia de relações paternalistas com a classe dominante, representada por comerciantes, coronéis e latifundiários. Segundo as observações de MURPHY (1960), o boom da borracha deixou marcas indeléveis sobre a vida dos índios Mundurucu, parte dos quais trabaIharam em seringais, passando a morar junto aos fornecedores brancos, dispersando as antigas aldeias.

A Pax (paz) comercial imposta pelo dominador branco na Amazônia acarretou, além da dispersão de comunidades indígenas, a coexistência de grupos tradicionalmente afastados ou mesmo hostis, alterando, em muito, os seus padrões de sociabilidade, produção e reprodução. Diluíram-se, rapidamente, as formas de organização política tradicionais centradas na guerra, e difundiu-se a prática da submissão a chefes brancos, ou a índios, homens de sua confiança, comprometendo-se, de maneira irreversível, a sua autonomia política.

\section{- A Situação Atual da Amazônia}

Conforme Martins, o Estatuto da Terra, imposto após o golpe de 1964, sob pressões americanas, visava medidas que modificassem a estrutura fundiária quando ocorressem tensões que pudessem conduzir a revoluções como a cubana (Martins, 1981, p. 95). A grande área, disponível para a remoção e assentamento de camponeses, desalojados pela concentração da propriedade ou removidos de áreas de tensão, era, exatamente, a área que correspondia à Amazônia e a partes do Centro-Oeste, sobretudo Mato Grosso, onde, conseqüentemente, passaram a se concentrar muitos lavradores, posseiros e pequenos proprietários expulsos de outras terras (Martins, 1981, p. 96; 105).

Pouco depois, esta política foi abruptamente alterada, passando a privilegiar não os desprovidos de terras, mas as grandes empresas que, por incentivos fiscais, eram estimuladas à implantação de grandes projetos agropecuários e de empresas mineradoras nacionais e multinacionais. Com isto, exacerbou-se o processo de concentração fundiária, propiciado pela abertura de um sistema rodoviário, visando desenvolver, a partir da década de 70 , a região de 


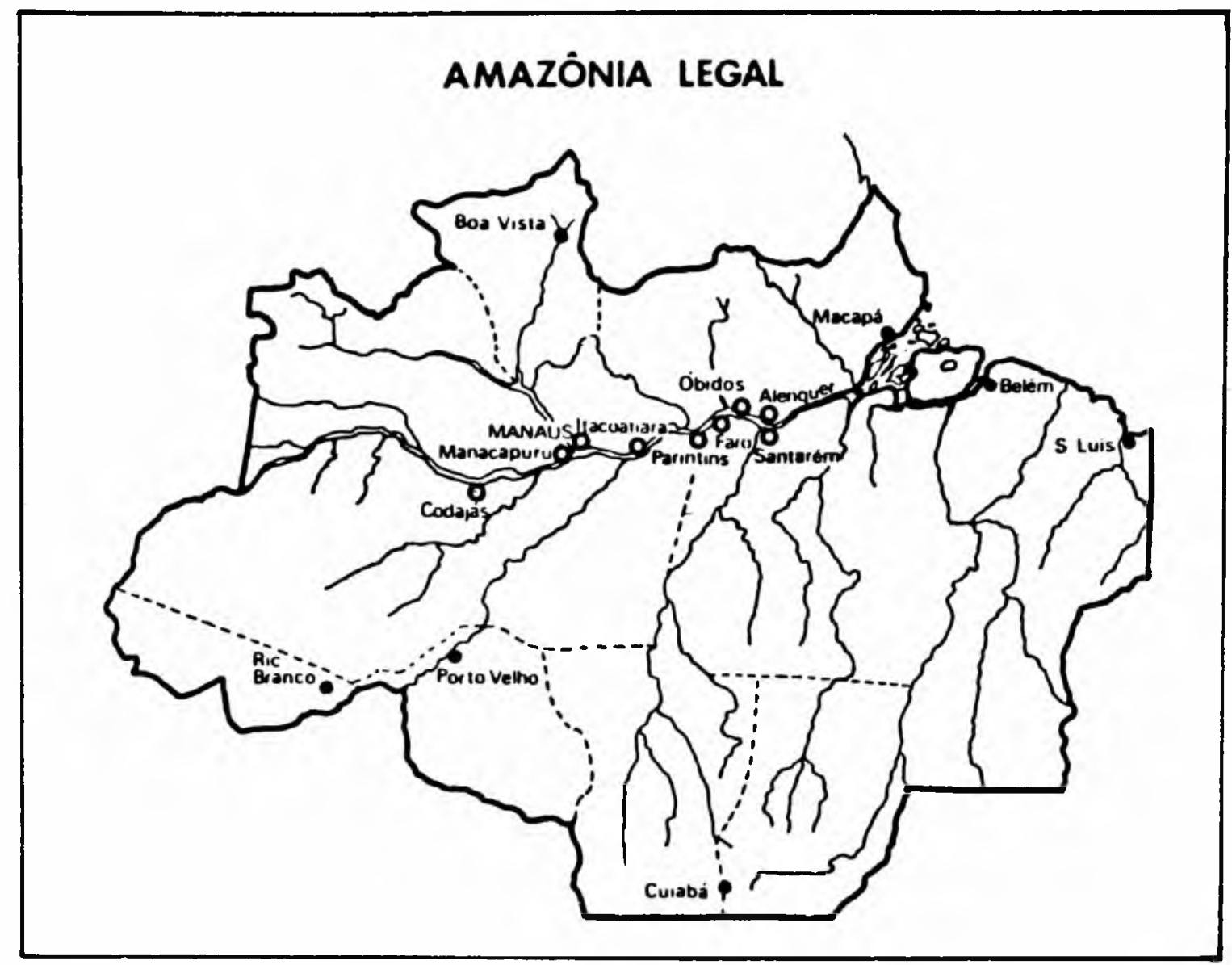

Fonte: MATTOS, C.M. Uma geopolítica Pan-Amazónica. Rio de Janeiro, José Olympio Editora, 1980. p. 70 .

Altamira. Segundo Almeida Mello, existe uma relação entre esta geopolítica de integração interna de valorização do espaço amazônico, mediada pela implantação do sistema rodoviário, e as estratégias de projeção externa do Brasil, tendo em vista o controle de suas fronteiras. Sob o ponto de vista geopolítico, o Projeto Calha Norte, por exemplo, nada mais é do que uma das estratégias elaboradas pelo Brasil para consolidar o acesso à área da Guiana e do Suriname (área de acesso norte), visando projetar-se externamente em direção ao Caribe.

A rapidez da sua aprovação pela Presidência da República e da sua implementação, apesar das fortes reações das entidades de apoio ao índio e da sociedade civil, preocupadas com os efeitos deletérios desta apressada ocupação militar em área de exploração dos índios Yanomami, deixa entrever que se trata de um esforço governamental e privado de objetivos estratégicos: impedir uma hipotética intervenção soviética que, apropriando-se da questão indígena, pudesse desestabilizar a fronteira brasileira (Santilli, 1987, p. 22). Se a tática da ocupação militar e da defesa de fronteiras só po- 

formações, que podem, ou não, redundar em sucesso. "Nem sempre (ou quase nunca), as políticas de ocupação resultam em desenvolvimento efetivo." (Santilli, 1987, p. 6), fato sobejamente constatado, não só pela história de ocupação da Amazônia, mas da de todo o território nacional.

Evidentemente, a rapidez do processo de ocupação e de desenvolvimento empresarial em grande escala exarcebou o número e a violência dos conflitos pela terra, coisa que se refletiu no grande número de decretos presidenciais visando a reforma agrária em áreas de tensão eclodindo em todo o território nacional (Martins, 1981, p. 96-99). E mais do que isso. As tensões sociais de outras partes do País, causadas pelo acentuado processo de concentração fundiária afetando o Brasil como um todo, instigou novas correntes migratórias do Sul e do Sudeste brasileiros em direção à Amazônia Ocidental, e do Nordeste, para a Amazônia Oriental (Martins, 1981, p. 119). Imagine-se as dificuldades de ajustamentos recíprocos entre representantes de áreas culturais, classes sociais e origens étnicas em nome de projetos de colonização e de desenvolvimento promulgados por um Estado autoritário que, desprovido de recursos, optou por liberar a Amazônia à ocupação dos interesses empresariais nacionais e multinacionais. Tal opção, apesar de todas as tensões sociais que acarretou para os camponeses e os indígenas, obedeceu à lógica do Estado:

19) garantiu a ocupação humana de uma imensa área, de grande importância geopolítica, mesmo que a custos sociais altos e indesejáveis;

29) propiciou a garantia da implantação de insumos mínimos que pudessem garantir o abastecimento de contingentes humanos de áreas interioranas muito isoladas, junto a fronteiras e outros pontos estratégicos do território nacional, visando assegurar a integridade do território nacional e a expansão das zonas de influência brasileira no continente sul-americano.

- Camponeses e Indios: um destino comum?

De acordo com José de Souza Martins, especialista no estudo da realidade agrária brasileira, poderíamos imaginar uma trajetória social comum entre posseiros (camponeses) e índios brasileiros da Amazônia Brasileira, tendo em vista uma dinâmica social típica, 
característica não só à região amazônica, mas a todo o território brasileiro.

Esta lógica baseia-se nos efeitos sociais acarretados pela renda fundiária, redundando numa lógica de concentração de terras e de expulsão sistemática de camponeses e índios das terras que ocupam. As frentes pioneiras, expressão de processos de incorporação de novas regiões pela economia de mercado, associadas a empresas agropecuárias, mineradoras, imobiliárias, comerciais etc., consideram a terra como mercadoria. Já nas frentes de expansão, representadas por contingentes humanos ainda não-integrados nas frentes pioneiras, a vida econômica não está baseada primordialmente nas relações com o mercado. Há uma dinâmica de interdependência entre as frentes de expansão e as frentes pioneiras, já que o fornecimento de excedentes produzidos pelas frentes de expansão só assumem valor de troca na economia de mercado. Camponeses e índios brasileiros ocupam áreas que correspondem a frentes de expansão, bem como a áreas de interesse geopolítico, subordinados ao Estado, que podem, ou não, implicar em interesses econômicos. Quando são de interesse econômico, na medida em que ocupam terras devolutas e terras tribais, camponeses e índios são freqüentemente atingidos por frentes pioneiras que, apropriando-se da terra, expulsam os seus ocupantes (Martins, 1975, p. 43-50).

"Posseiros e indios desejam a ocupação e o usufruto da terra, não a sua propriedade enquanto mercadoria. Contudo o posseiro é produto da expansão do capital, o índio não o é; o posseiro pode ser indenizado pelo seu trabalho, como um dos recursos para removê-lo da terra pretendida pela fazenda ou empresa.

o índio não pode. A terra é sagrada, nela se baseia a organização tribal" (Martins, 1981, p. 117)(1)

A partir desta perspectiva, o índio constitui um entrave aos desdobramentos históricos da lógica da renda fundiária, já que, incidindo sobre as frentes de expansão, acaba gerando tensões entre estas e as sociedades indígenas (Martins, 1975, p. 47). Desta forma, o camponês está fadado a disputar com o índio a terra necessária para ele, membro da frente de expansão, e para o índio, indis-

(1) Segundo a legislaçáo brasileira, as terras tribais são propriedade da União, enquanto os indios detêm a sua posse $e$ usufruto. Por esta razão, cabe ao governo federal providen. ciar as garantias da integridade destas terras indígenas por meio da decretação, delimitação e demarcação de reservas destinadas à ocupação e exploração dos índios. 
pensável à manutenção de um patrimônio fundiário que garanta poder permanecer "fora" do mundo capitalista civilizado, cujos valores ele, veemente, rejeita.

Do ponto de vista da mobilidade física e social, o camponês é, antes de mais nada, um nômade, deslocando-se rapidamente de uma para outra área do território nacional, para trabalhar como mão-de-obra barata em fazendas ou empresas e cultivar um pequeno pedaço de terra. Com o cultivo, visa a sobrevivência de si mesmo e de sua família, além da venda de excedentes comerciáveis para a compra de recursos indispensáveis, endividando-se e submetendo-se, pelo voto, a chefes políticos locais ou regionais, por vezes, pelo mero direito de morar em um pequeno pedaço de terra (Martins, 1981, p. 45; 47).

O mesmo não ocorre com o índio. Este podia locomover-se mais livremente antes do controle estatal instaurado por meio das reser. vas, administradas por chefes de Postos Indígenas e missionários que, encarregados de zelar pelo seu funcionamento interno e pela integridade física dos índios, seus tutelados (vide adiante a seção: O Indio e o Estadol, passaram a interferir nos padrões de mobilidade espontâneos de índios e comunidades indígenas inteiras.

Em inícios deste século, registraram-se numerosas migrações espontâneas por parte de grupos indígenas, por vezes geradas por decisões internas, por vezes, decorrência dà pressão exercida por colonos, lavradores, garimpeiros, criadores de gado e pequenos proprietários. Tais migrações remontam ao século XVI, quando grandes contingentes Tupinambá migraram para o Norte do País, para, em seguida, embrenhar-se nas áreas interioranas mais afastadas, inacessíveis ao civilizado, geralmente áreas de terra firme, junto a cabeceiras de rios. Com isso, houve a redistribuição espacial dos grupos, grande redução demográfica e profundas transformações sócio-culturais (reaglutinação por intermédio de novas alianças e aculturação intertribal) em áreas de terra firme, geralmente menos bem aquinhoadas em termos de solos cultiváveis do que aquelas que tradicionalmente lhes era dado explorar.

O avanço desordenado das frentes de expansão, fruto da concentração fundiária na zona litorânea, exacerbou as tensões entre índios e civilizados. A construção de ferrovias e linhas telegráficas, visando a abertura de áreas do Brasil interiorano, incidia em territórios de ocupação de indígenas que reagiam violentamente. $A$ 
exacerbação das tensões levou à fundação do Serviço de Proteção aos Indios e à criação das primeiras reservas indígenas pelo marechal Rondon, representante do governo federal. Garantir a integridade das populações tribais naquele momento (segundo o lema "morrer, se preciso for, matar (o indio) nunca!') significava atribuir-se o direjto, por parte do Estado, em interferir nos destinos e nas terras dos grupos indígenas brasileiros, em nome de valores humanitários reiterados pela população urbana da época. Segundo a visão positivista deste humanitarismo, os indios deveriam ser sistematicamente atraídos, pacificados e ensinados a integrar-se como mão-de-obra na sociedade nacional. Por outro lado, algumas destas terras indígenas, ao se subordinarem ao governo federal, acabaram por assumir importância estratégica para o Estado brasileiro ao mesmo tempo em que a sua salvaguarda, implicando na proteção dos seus ocupantes, as comunidades indígenas, passaram a desfrutar de uma política ideal de cunho protecionista, internacionalmente muito elogiada. Infelizmente, tal política acabou sendo desvirtuada, pois o antigo Serviço de Proteção ao Indio-S.P.I., posteriormente substituído pela Fundação Nacional do Indio-FUNAI, acabou por vender ou mesmo considerar como territórios vazios, não-ocupados por índios numerosas glebas, quando se tratava de fazer acordo com grandes empresas, projetos tecnocráticos e latifundiários de grande influência regional. O processo atual de avanço das frentes civilizadas é tão rápido que torna inócua qualquer tentativa efetiva de proteção das reservas mutiladas por rodovias, cercas e demais modalidades de invasão.

Segundo Cardoso de Oliveira, os Postos Indígenas, sediados nas reservas Terena e Tukano, teriam propiciado condições de resistência à assimilação destas duas tribos, já integradas na estrutura sócio-econômica regional (Cardoso de Oliveira, 1978, p. 26-27). A atuação dos Postos teria possibilitado a regeneração das condições demográficas necessárias à continuidade de formas de aliança tradicionais. Trata-se pois de influência favorável à manutenção dos padrões culturais indígenas. Segundo nossas próprias observações entre os índios Bororo, cobrindo um período que vai de 1970 a 1986, os Postos bem como as missões chegaram, por diversas vezes, a dificultar ajustes migratórios tradicionais dos Bororo. Indispensáveis à preservação da dinâmica da vida tradicional desta tribo, as flutuações, em termos de migrações temporárias ou mesmo-mudanças de uma para outra aldeia da mesma tribo, devem ser autorizadas pelos 
chefes de Posto e pelos missionários, mormente quando envolvem deslocamentos para centros civilizados. Desta perspectiva, também ocorrem adaptações por supressão dos padrões indígenas tradicionais.

Conforme as pressões externas sobre as reservas indígenas, os Postos podem adquirir o caráter de refúgios, garantindo os mínimos vitais à sociabilidade tradicional indígena. $O$ índio, por encontrar barreiras sociais, não poderia diluir-se no mundo dos civilizados. Quando deseja integrar-se, o faz de forma seletiva, desenvolve estratégias próprias ainda pouco estudadas pelos antropólogos. Embora tenham emergido lideranças indígenas em nível regional e nacional por influência da Igreja, constata-se uma grande defasagem entre as concepções dos jovens líderes indígenas, que vivem fora das suas comunidades de origem, e as dos chefes comunitários, os velhos, que conduzem os processos políticos ao nível local. As lideranças jovens utilizam estilos e imagens da oratória muițo mais civilizadas do que indigenas. Expressam a adaptação, por parte do índio, às instituições políticas e religiosas da sociedade brasileira, que o transformam num indio genérico, o meio de barganhar pela proteção oficial, claramente estabelecida por lei.

O camponês, apesar de desfrutar de uma situação jurídica muito indefinida e encontrar-se como "anomalia, como pessoa que está numa situação provisória. " (Martins, 1981, p. 105) está, em termos culturais, muito mais dentro do sistema do que o índio, por sua vez, aquinhoado com uma legislação mais definida. É que $o$ camponês, quando perde as suas terras, perde apenas as suas condições de trabalho e os frutos da energia nelas dispendidos, visando o seu sustento e o de sua família. Diferentemente do índio, o camponês pode regenerar o seu modo de vida com relativa facilidade em qualquer outro pedaço de terra, que corresponda aos mínimos de produtividade. Isto porque, integrado nos padrões culturais, sociais e tecnológicos predominantes, o camponês pode regenerar as suas formas de sociabilidade, vigentes na maior parte das áreas rurais brasileiras, e baseadas nos mesmos padrões de clientelismo, coronelismo e compadrio, cultivo à base de uma tecnologia rudimentar e um catolicismo rústico.

Já o índio, quando desalojado e removido de suas terras, considera-se desvinculado de sua própria condição de existência física e espiritual, um perdedor de um si mesmo, indissoluvelmente ligado 
às terras. Nelas, dormem os ossos dos seus ancestrais que regeneram os recursos que alimentam, embelezam e dignificam a convivência dos vivos. Daí a resistência à remoção, a luta pela manutenção das reservas e o empenho em recriar, modificar e viabilizar os padrões culturais mais importantes dos grupos, gerando um fluxo cultural justaposto - mas nunca dentro - da história cultural do dominador civilizado.

$O$ índio, apesar de atrelado aos avanços e recuos das frentes de expansão e sujeito à superexploração (1), considera-se ligado a uma tradição pré-colombiana muito específica, irredutível e imorredoura. Esta, metamorfoseada por aparências históricas inovadoras, continua resguardando o núcleo da sua auto-imagem, base dos seus movimentos de resistência e de suas reivindicações. Em vez de migrar, como o camponês, o índio enquista-se nas terras comunitárias que the restaram nas reservas junto aos Postos e às missões, oficialmente encarregados de zelar por seus interesses. Eis uma tarefa difícil de ser cumprida, face aos impactos das frentes de expansão e das influências mais deletérias dos interesses empresariais.

O enquistamento visa garantir a persistência de comunidades indígenas ocupantes de terras invendáveis, o que, como não poderia deixar de ser, as torna um evidente obstáculo aos avanços da sociedade nacional. A pacificação, sedentarização e intensificação do cultivo impostas por meio das reservas a sociedades indígenas, tradicionalmente guerreiras, sazonariamente migrantes, nem sempre redundaram no aumento das suas chances de sobrevivência, segundo GALVĀO (1979). É necessário lembrar também que este processo de enquistamento ou fechamento já é fruto da reação dos efeitos negativos do contato interétnico. Antes da interferência do civilizado, presume-se que tenha ocorrido maior número de flutuações populacionais, migrações sazonárias e deslocamentos espontâneos entre aldeias e regiões diversas, propiciados por incursões guerreiras, atividades de caça e de coleta etc. Com a intrusão do dominador, as populações indigenas foram compelidas a novas formas de ocupação do espaço e a ritmos de trabalho diversos. E, dos grupos tribais que lograram sobreviver na nova ordem, exigiu-se

(1) Segundo Martins, na troca desigual, "um indio que mais vende do que compra. . pro. duz o lucro extraordinário próprio da situação de superexploração, recebendo pelo produto do seu trabalho mercadorias cujo valor é menor do que o valor que criou. essa lógica perversa do capital atenua o impacto da mercadoria e do mercado nos grupos tribais, ao mesmo tempo que os obriga a recriarem suas condições de subsistência segundo suas próprias tradições, ainda que adaptadas" (Martins, 1986, p. 28). 
formas profundas e rápidas de transformação sem que, com isto, deixassem de persistir certas atividades, geralmente de cunho ritual, modificações, por vezes, exacerbadas de padrões cerimoniais indígenas tradicionais. Mesmo as culturas indígenas menos isoladas são apenas parcialmente integradas, embora, sob o ponto de vista econômico e político estejam se abastecendo, cada vez mais, com recursos materiais e tecnológicos de fora, comprados a dinheiro ou trocados nos núcleos de ocupação civilizada(1).

A dinâmica das relações entre civilizados e índios não pode ser reduzida à dinâmica das relações entre classes sociais. Bonfil concebe-a como uma relação dialética entre culturas indígenas e nacionais (Bonfil, 1981, p. 97), e, Cardoso de Oliveira, como sistemas de "frição interétnica"(2) . razão pela qual, segundo as circunstâncias, apesar de sua pobreza, compartilhada enquanto classe de explorados, camponeses e índios podem vir a opor-se uns aos outros, deixando, assim, de ter um destino comum.

\section{O INDIO E O ESTADO}

Segundo a Constituição, o índio não pode exercer todos os seus direitos de cidadão. Na medida em que dispõe de uma capacidade jurídica apenas relativa, necessita de um tutor, que deve zelar pelos

(1) Os estudos sistemáticos de Posey entre os Kayapó e os demais ecólogos culturais que trabalharam na Amazônia Brasileira, principalmente Gross, revelam a importância assumida por determinadas tradições culturais em especial, de cunho cerimonial, para as condições de sobrevivência das comunidades indigenas da atualidade. Trata-se, na verdade, de outros modos de produção, que, além de gerarem satisfação ética e estética, se justapõem ao sistema de produção do dominador, o sistema de produção capitalista. Segundo nos demonstram os estudos recentes feitos na Amazônia, a capacidade de suporte destes modos de produção tradicionais de natureza tribal envolve um sofisticado planejamento espácio-temporal das atividades de produção, da politica demográfica das formas de ocupação do espaço físico visando a obtenção de recursos diversificados espalhados pelos territórios indigenas. A sofisticação destas técnicas adaptativas aos seus respectivos microambientes é totalmente ignorada pelos administradores civilizados o que, acrescido das invasões das reservas, inviabiliza a manutenção da dinâmica de abastecimento tradicional, dolorosamente interceptada por perdas territoriais e pela imposição de novos padrões de trabalho.

(2) A concepção de "fricção interétnica" seria o equivalente etnológico à concepçร̃o sociológica de "lu ta de classes" (Cardoso de Oliveira, 1978, p. 85). (. .) "Como os fins tendem a ser contraditórios (pela própria natureza do 'sistema interétnico'), podemos dizer que - pelo menos em determinados momentos - a sobrevivencia indigena, bem como sua integração regional, será função da não articulação dos regionais com referência a seus proprios fins" (Cardoso de Oliveira, 1978, p. 89). Associada d idéia de "sistema interétnico" está a de "potencial de integração", idéia esta do autor que se assemelha d̀ de "potencial de adaptação", muito trabalhada pelos ecólogos culturais (Sahlins, 1966). 
seus interesses. A tutela do índio cabe a representantes autorizados pelo Estado, os integrantes da $\mathrm{FUNAI}$, e a certas ordens religiosas por ele determinadas, que mantêm missões nas zonas interioranas do Brasil.

Os interesses do indio foram considerados relevantes apenas durante o período inicial de existência do Serviço de Proteção ao Indio-S.P.I., ao tempo em que era vivo o marechal Rondon, o seu fundador. Após 1930, dado o pouco prestígio de Rondon junto ao governo Vargas, o S.P.I., por falta de verbas, deixou de corresponder às expectativas, primando pela corrupção, pelo que acabou tendo que ser extinto. Em 1967. foi substituído pela Fundação Nacional do Indio-FUNAI, que logo tentou restabelecer a credibilidade do órgão com a criação de diversos parques, em áreas ocupadas por grupos tribais. Contudo, esta política durou pouco para ser substituída por outra, que visava integrar os índios, do modo mais rápido possível, como mão-de-obra para uma tarefa nacional gigantesca: a abertura e o desenvolvimento da Amazônia (Davis, 1977, p. 56). Reintroduzida a renda indígena, que havia causado fortes críticas durante os últimos anos de existência do S.P.I., exigiu-se o trabalho forçado dos índios para o Posto, sem que estes se beneficiassem dos lucros. Auspiciada pela própria FUNAI, a renda visava transformar os Postos em empresas lucrativas, com o objetivo de pagar funcionários, projetos agropecuários desenvolvidos em qualquer área indígena, em coordenação com o programa de abertura de estradas, que exigia a rápida contatação, pacificação e remoção de tribos hostis (Davis, 1977. p. 57-58).

Apesar de toda a legislação favorável ao índio, a prática confirma que, nos momentos críticos, a FUNAI tende a se omitir nos assuntos que interessam ao índio, seja por ordem de instâncias oficiais superiores, tal como o Conselho de Segurança Nacional, seja por pressões bem organizadas de latifundiários e grandes empresários.

A omissão da FUNAI vai contra os interesses dos seus tutelados, os indígenas, razão pela qual as entidades de apoio ao índio brasileiro têm se empenhado em cobrar constantemente, aos seus representantes, os deveres decorrentes da tutela.

Segundo Dallari, as riquezas do subsolo brasileiro interessam principalmente a empresas estrangeiras, favorecidas pelo complexo militar-tecnocrático, que decide os destinos do País, contando com a anuência da própria FUNAl (Dallari, 1985, p. 56-57). Esta prática governamental contradiz a própria Constituição e o Estatuto do in- 


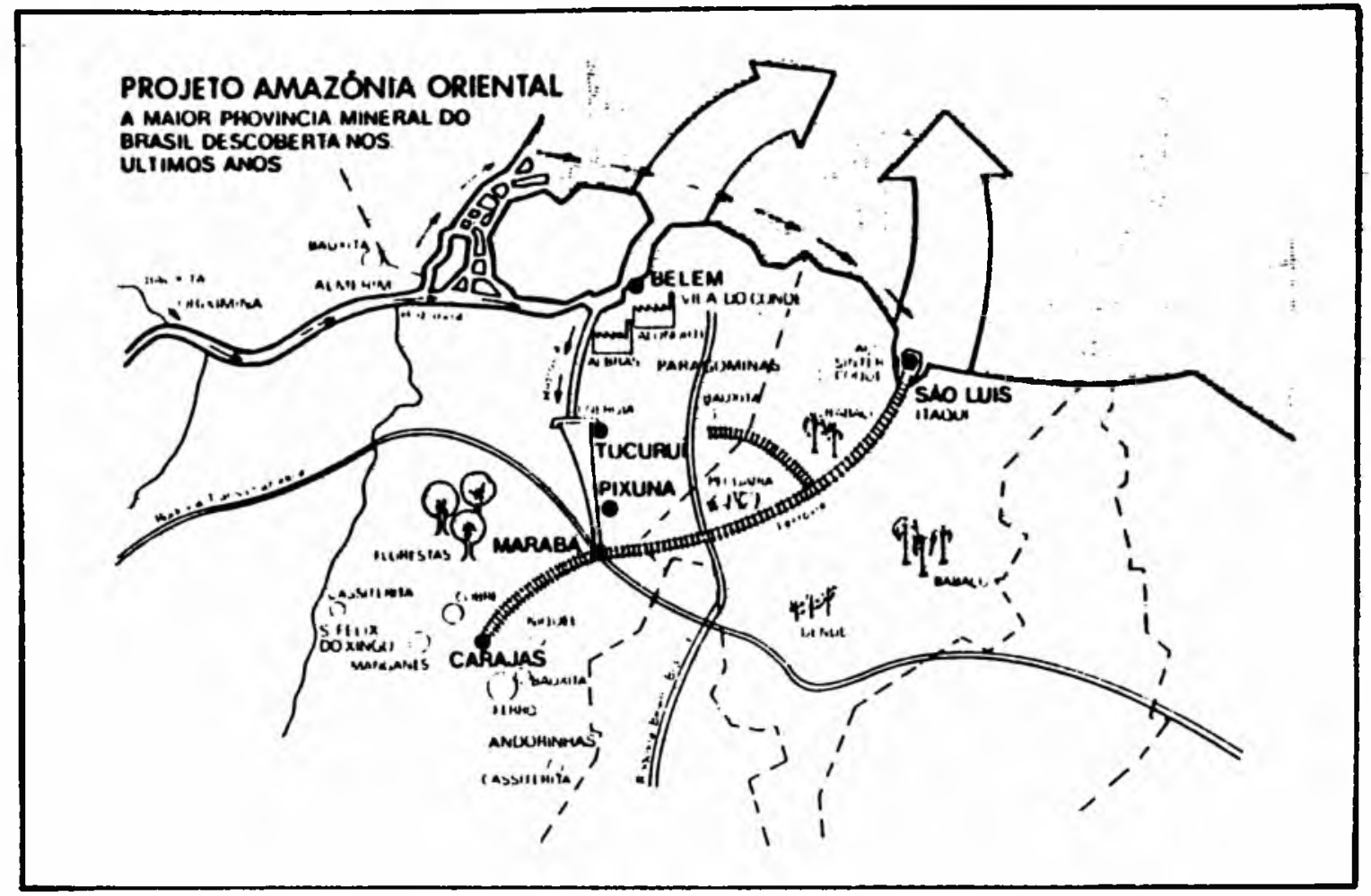

Fonte: MATTOS, C.M. Uma geopolítica Pan-Amazônica. Rio de Janeiro, José Olympio Editora, 1980. p. 111.

dio, que asseguram aos indigenas a posse permanente das terras que ocupam, além do usufruto exclusivo de todas as riquezas nelas existentes. A regularização jurídica destes grandes projetos de mineração é feita pela Cia. Vale do Rio Doce Navegação-DOCENAVE, todos acolhidos pela FUNAI. A documentação é fornecida com incrível rapidez, padrão inusitado para quem é obrigado a sujeitar-se à morosa burocracia da FUNAI.

A política indigenista oficial preconiza, portanto, uma defesa imaginária das culturas indígenas, metáfora muito usada nos discursos oficiais, ao mesmo tempo em que desmantela, de forma irreversível, os cenários obrigatórios destas culturas:

as terras e os delicados ecossistemas regionais e locais que as afetam, profundamente lesados, se não, destruídos pelo avanço desordenado das frentes pioneiras e das frentes de expansão.

No caso da mineração, os avanços das frentes deixam rastros irrecuperáveis. Longe de se limitarem a causar distúrbios bióticos e ecológicos graves, provocados por desmatamento e cultivo intensivo predatórios, as frentes de mineração representam a própria sentença de morte das terras que, profundamente trabalhadas pelas máquinas, não poderão regenerar a sua cobertura vegetal nem a fauna que dela depende. 
Do mesmo modo, a construção das grandes hidrelétricas, que inundam amplos territórios, tradicionalmente ocupados pelas populações ind ígenas, associada à mineração intensiva, tornam extremamente penosas as novas condições de sobrevivência dos índios que, removidos compulsoriamente de suas terras de. origem, poderão ou não lograr suportar os impactos das doenças e da desorganização social, invariavelmente associados a tais práticas de interferência governamental.

\section{A CONSCIẼNCIA DO PROCESSO}

- Imagens e Estereótipos do Indio Brasileiro

Segundo Cardoso de Oliveira, os índios são alvo de vários estereótipos elaborados em função do desconhecimento da realidade que vivem. São vistos como bons, ingênuos, posição que, inspirando-se na literatura romântica brasileira, caracteriza a imagem do índio por parte do homem das cidades. Já para o homem rural, ele é perigoso, ruim, em função das constantes tensões em que vive com os representantes de determinadas sociedades tribais (Cardoso de Oliveira, 1978, p. 65-72).

Nas cidades, apesar das campanhas de esclarecimento quanto aos problemas do índio, apoiadas pelos meios de comunicação de massa, pouco se consegue em termos de pressões reais sobre as autoridades governamentais, já que os impactos mais deletérios sobre os índios são desencadeados por grupos econômicos regionais, pouco controláveis pelo governo central (Cardoso de Oliveira, 1978, p. 69).

Em áreas interioranas como o Mato Grosso, por exemplo, mais próximas dos focos de tensão entre latifundiários, posseiros e índios, os mesmos meios de comunicação, em especial o rádio e o jornal, são utilizados para desencadear campanhas contra os índios. O objetivo é expulsar os poucos remanescentes indigenas, que não trabalham as terras tão vastas e tão boas das reservas, já que, geralmente, são menos erodidas e depredadas do que as do civilizado. Este argumento reflete a "mentalidade estatística" (Cardoso de Oliveira, 1978, p. 71), realçando a grande quantidade de civilizados sem terras e tantas terras ocupadas por tão poucos índios. Outro argumento que instiga à agressão e à violência locais contra os índios é o de que seria necessário aumentar a produtividade para obter lucros o mais rápido possível, para que possam 
funcionar as empresas estabelecidas em áreas tidas como vazias mas que, na verdade, constituem territórios de exploração do índio, conforme a "mentalidade empresarial" (Cardoso de Oliveira, 1978, p. 73). E, mais do que isto, os índios devem pagar, e realmente o fazem, por meio da renda indigena, reinstaurada pela FUNAI, pelos benefícios que recebem do governo. Fica patente, portanto, que a política indigenista oficial do governo brasileiro inspira seus argumentos numa mentalidade própria aos detentores das grandes empresas.

O problema mais sério é que estes estereótipos são sistematicamente regenerados pelo processo de socialização informal e formal das crianças brasileiras. Pertencer ou não a uma família de advogados, residente em São Paulo, de grandes empresários ou posseiros, na Amazônia, é um ponto de partida decisivo para o processo de desenvolvimento por parte da criança civilizada de atitudes frente aos estímulos sociais associados ao índio:

- a convivência imaginária, representada por filmes, campanhas televisionadas, livros didáticos e de recreação, dias de comemoração ao índio celebrados nas escolas; ou

- à convivência real, representada por vivências de relações interétnicas mais ou menos tensas.

\section{- O Indio nos livros didáticos}

Nos livros didáticos oficiais, adotados em toda a rede de ensino público, o índio aparece como um índio genérico, embora as ilustrações correspondam a traços culturais de cultura Tupi. Nada se diz aırespeito de eventuais diferenças lingü ísticas e culturais, negando-se assim a sua grande variedade cultural. Esta só poderia ser transmitida às crianças se não fosse dificultado falar dos diversos espaços físicos - portanto, terras - e diversas histórias de relações com o branco portanto, agressões, massacres e violências - responsáveis por tais diferenças culturais $(1)$

(1) Quando tive a oportunidade de participar de um programa de televisão destinado a um público infantil, não me foi permitido mencionar que os indios atuais tivessem problemas de terras, já que o interesse era divulgar diferenças culturais de costumes exóticos, rotinas diárias e formas de vida religiosa. A proibição tinha vindo do governador do Estado de São Paulo, o sr. Paulo Maluf. 


\section{- A história do Brasil e o Indio}

Nos livros de história do Brasil, o personagem Indio aparece apenas nas primeiras páginas, quando oferece alimentos e assiste à primeira missa católica com os portugueses, que haviam vindo com o descobridor destas terras do pau-brasil, Pedro Álvares Cabral. Nas páginas subseqüentes, Indio desaparece. Não é de se estranhar pois, que, quando chegam às nossas universidades, os estudantes não deixem de perguntar: "Mas estes indios ai, de que você tanto fala, estes. Bororo? Eles já não acabaram?"

\section{- O Indio na literatura infantil}

A literatura infantil brasileira ligada ao índio também tende a privilegiar mitos e lendas, que, adaptados ao pequeno público, são muito bem ilustradas sob ponto de vista estético, nem sempre correspondendo a desenhos fiéis à realidade etnográfica. A interpretação de mitos, se já é difícil para especialistas adultos, acaba gerando estereótipos nas crianças não-indígenas, em função do caráter bizarro e incompreensível das histórias demasiado desligadas das suas experiências de vida. Por que esta predileção por mitos se, em nossas escolas, também não nos valeríamos de trechos densos e sofisticados do Velho ou do Novo Testamento (adaptados aos catecismos quando destinados aos jovens) para falar de nossa própriasociedade? Acredito que a ênfase em mitos realça uma intenção de alheamento da criança em relação ao índio. Procurar ver no índio expressões miticas ou estéticas constitui, na verdade, uma forma de relegá-lo ao artístico, ao imaginário, em suma, ao exótico, ao que está fora de nossas vidas e que pouco nos atinge(1).

(1) Segundo Martins, "o desconhecimento da vida e da realidade do camponês, e sobretudo da história dos camponeses, leva a uma superestimação dos misticismos e ao desconihe. cimento das formas peculiares do seu materialismo" (Martins, 1981, p. 31). Ao meu ver, o mesmo acontece com o índio que, pouco conhecido, dá margem a especulações de caráter mítico e místico. Segundo os trabalhos de antropólogos inspirados pela Eco. logia Cultural, tais misticismos e crendices são, na verdade, "representacỗes estereotipadas" de formas de conhecimento e de práticas que correspondem a padrões adaptativos indispensáveis à sobrevivência física, material e moral dos indigenas. Além disto, se mito não é história pois, no caso do indio, esta última se inscreve não só em tradições orais mas também em práticas sociais (tecnologia, cermonialismo etc.), associar o indio ao mito é associá-lo a uma não-verdade histórica para a criança não-indigena. 


\section{- A Igreja e o Indio}

Também a Igreja brasileira, por parte dos adeptos da doutrina tradicional, não deixa de contribuir para uma imagem do índio estereotipada pelo sofrimento, imprescindível à sua redenção, à imitação de Cristo, "Agnus Dei", que teve de ser imolado para alcançar o seu lugar junto ao Pai celestial. Justifica-se pois o sofrimento dos indígenas como inevitavelmente ligado à lógica do mito cristão.

Em suma, estético ou repelente, ingênuo ou perigoso, indolente ou sofredor, tais estereótipos nos retratam sempre um índio genérico, concepção esta profundamente arraigada à consciência que tem o civilizado de alguém fora e distante, razão pela qual não importa desprovê-lo, efetivamente, dos seus mínimos vitais e sociais. Este caráter genérico do índio também permeia toda a legislação brasileira que, apesar de inspirada em valores humanísticos visando protegê-lo, não logrou impedir que ele fosse expoliado do seu tempo e do seu espaço reais, imprescindiveis à sua regeneração, em termos dignos, pela política indigenista oficial dos últimos cinqüenta anos.

\section{- Imagens e Estereótipos do "Civilizado" Brasileiro}

As imagens construídas pelos índios em torno do civilizado ou branco também são genéricas. Nas comunidades'indígenas, os conhecedores das tradições, os velhos, inserem-no em relatos míticos que, de maneira geral, tendem a ressaltar dois pontos:

- primeiro, que o civilizado foi criado por eles próprios, criatura ambígua e incontrolável que acabou tendo que ser afastada para longe;

- segundo, que o civilizado é dotado de poderes mágicos desmesurados, já que traz consigo artefatos sofisticados, dinheiro, armas de fogo, cachaça forte, além de difundir feitiços (doenças) mortais.

Dados estes poderes imensos, o civilizado pode roubar muita terra, parentes e a própria auto-estima do índio, tornando-o um pobre, sem o apoio tradicional de numerosos parentes, sem mulheres para casar, sujeito à sedução dos recursos materiais estranhos que não consegue produzir.

A atribuição de poderes mágicos ao branco decorre do desconhecimento, por parte dos indígenas, dos padrões culturais de nos- 
sa sociedade. Ao ver dos velhos, a dinâmica de nossa sociedade é incompreensivel e absurda, pelos efeitos destrutivos que acarreta, o que se pode perceber a partir do desabafo de um velho Bororo, Mano Kurireu, da missão salesiana de Sangradouro, que me dizia:

"Vocês, 'civilizados' não têm respeito por nada, não têm lei, nem religião!"

Coincidentemente este é o mesmo desabafo dos primeiros portugueses que, obrigados a conviver com os estranhos Tupinambá da costa brasileira, no século XVI, de que dependiam para obter a mão-de-obra necessária à extração do pau-brasil e conseguir os alimentos, diziam tratar-se de "selvagens" que não tinham "nem fé, nem lei, nem rei" $\mathrm{O}$ desconhecimento recíproco de grupos humanos forçados ao contato engendra temores, por sua vez canalizados, sob a forma de atribuição recíproca de qualidades mágicas e místicas dos agentes sociais envolvidos.

Esta concepção de um civilizado magicamente poderoso, até hoje sustentada pelos sábios tribais, diverge daquela que têm os jo. vens líderes indígenas da União das Nações Indígenas-UNI que, apesar de não conhecerem em maior profunidade suas culturas de origem, pelo fato de viverem nas cidades como Brasília, Cuiabá e São Paulo, defendem a preservação das diversas identidades étnicas, isto é, seus direitos sociais em continuar vivendo, de acordo com padrões culturais próprios, não-civilizados, vistos como simples roupa para defender seus próprios interesses. Apesar da diferença de objetivos, os jovens líderes indígenas usam imagens, metáforas e estereótipos fortemente inspirados na oratória política do civilizado(1) $^{(1)}$

Nos idiomas indígenas, geralmente, ocorre um rótulo lingüistico único para denotar todo e qualquer representante do mundo civilizado, seja ele de origem urbana, rural, nacional ou estrangeira.

(1) Em seu depoimento do Folhetim de 3 de maio de 1981, p. 5, o indio Marcos Terena, fundador $e$ atual presidente da União das Nações Indigenas, fala a certa altura: " 0 indio não é um elemento econômico. Ele não produz, mas tem capacidade para aprender a fazer isso" (grifo da autora). Ora, o índio sempre produziu, só que dentro de um padrão de trabalho e um sistema económico tradicionais, que não visam o lucro. Mais adiante, o jovem indio Terena continua: "Lá na aldeia não temos lendas, só crendi. ces. "fica patente a conotaçáo pejorativa dispensada às lendas e crendices, que, afinal, nunca deixaram de existir nas comunidades locais. Por vezes podem tornar-se cada vez mais sigilosas, mas nunca deixaram de ter importância, já que constituem recursos indispensáveis à preservação daquele mínimo de tradições, necessário à resistência, frente aos impactos culturais, materiais e espirituais do civilizado. 
Por vezes, como entre os índios Bororo, pode ser feita uma diferenciação de categorias à base de características raciais tais como a cor da pele. Representantes da FUNAI, religiosos, políticos, assistentes, enfermeiros, comerciantes e pesquisadores, apesar de comportamentos sociais diversos quando estão em contato com as comunidades indígenas, são vistos como tendo sempre um único objetivo: burlar o índio com falsas promessas e mentiras, tirar-lhe o pouco de terras, enfeites tradicionais, mitos, danças e cantos que Ihe restam por meio de fotos, fitas e filmes, posteriormente vendidos nas grandes cidades, tornando rico (enricando) o civilizado e empobrecendo o índio, o verdadeiro dono de todas estas riquezas.

A encarnação do máximo de expoliação possível é associada aos paulistas, donos efetivos das maiores glebas do Interior do Brasil e associados ao grande capital, personagens igualmente temidos pelos camponeses ${ }^{(1)}$

Imaginemos agora a experiência de uma civilizada antropóloga paulista, vivida entre os Bororo do Mato Grosso, em 1986. As dificuldades de entrada na reserva foram muito grandes pois, tanto para os índios quanto para os próprios civilizados, representantes locais da FUNAI, o antropólogo é, antes de mais nada, um preguiçoso, porque não trabalha na roça para comer. É também um perigoso explorador, um ladrão das riquezas culturais do índio que, como todo bom civilizado, só vai pensar em trocá-las por dinheiro. 0 antropólogo tem dinheiro pois, se não o tivesse, não poderia ter vindo de tão longe, carregado de tantas coisas e tão cheio de saúde. Se ele tem dinheiro é porque logrou acumulá-lo de forma indevida:

- primeiro, porque vendeu riquezas culturais que não lhe pertenciam, mas sim, ao índio;

- segundo, porque, ao permitir-se tal liberdade, deixou de dar o dinheiro e os imensos benefícios obtidos pela venda destas riquezas àquele que as criou, $o$ índio.

Em suma, quem acumula dinheiro só pode ser mau, e a acumulação de bens e dinheiro, representada pelo "civilizado antropólogo", evidencia que este, além de mau e "rico", não é amigo do "indio", "pobre" (Martins, 1986).

(1) Segundo Martins, a besta-fera, um personagem do Apocalipse, é associada ao dinheiro que, segundo o posseiro amazánico, possui um caráter perverso e demoniaco, um inimigo, que representa a opressáo política e a perda da liberdade (Martins, 1981, p. 132; 135). 
Ser amigo não é ter, mas dar riquezas (Clastres, 1977), característica dos verdadeiros chefes, dominadores, que sabiam corresponder às infindáveis cobranças dos seus súditos. Tais cobranças 1t trazer. barcos, construir pontes e estradas, abter um caminhão, organizar muito dinheiro etc.) representam um ônus financeiro insuportável para antropólogos e entidades de apoio que não pudérem contar com a disponibilidade constante de vultosas somas de dinheiro. Isto se torna desastroso para a continuidade de projetos de pesquisa alternativa, desengajados daqueles auspiciados por entidades financeiras tais como o Banco Mundial dos EUA que, por meio de grandes somas de dinheiro, desenvolve projetos de interferência junto às comunidades indígenas, que contam com todo o apoio da política indigenista oficial (Viertler, 1987).

A barganha pelo dinheiro instaura um forte faciocismo dentro das aldeias indígenas, entre as diversas comunidades de mesma tribo e entre diversas etnias indígenas junto à FUNAI, à Igreja, a entidades de apoio e aos próprios pesquisadores. Este processo interfere, cada vez mais, conforme o grupo tribal esteja mais ou menos isolado, nas condições de realização de pesquisas de campo, já que o antropólogo șe vê na obrigação constante de participar ativamente na vivencia de graves problemas econômicos e.politicos que se abatem sobre as comunidades em que se encontrá. E evidente que, por maior que seja o seu envolvimerto pessoal, isto em pouco afeta a virutencia de prósessos spciais que, de certa forma, reftetem 0 facrocistiof existente entfe os prophrios representantes đa sóciedade nacional brasileira.

Dentro da conjuntura atual de problemas que envolvem as populações indígenas da Amazônia Brasileira, só me resta perguntar:

- Qual o futuro destas populações que nas as submeta à corrupção desenfreada, ă besta-fera tão temida porque consegue tudo o que quer, inclusive arrapcar dos velhos os seus segredos mais caros?

- Que tipo de dados o antropólogo logra coletar em tais circunstâncias? Tratar-se-ia de valores e práticas sociais ainda plenos de sentido e de afetividade, ou estaremos lidando com dados-mercadorias, que sabemos, por vezes, inventados pelos indios, visando barganhar a obtenção de recursos materiais trazidos pelo pesquisador? 
- E, finalmente, o que representa esta nossa Antropologia Social e Cultural neste contexto?

Nota-se que as identidades étnicas, na medida em que retratam o fluxo de criação cultural constante que uma população indígena é obrigada a desenvolver para lograr adaptar-se a inovações do seu ambiente de vida, são muitas vezes construidas por meio de elementos sociais e materiais não-indígenas, embora a intenção última seja sempre a de garantir um modo de vida alternativo à do civiliza. do. Estas criações culturais sofreram, em muito, pressões advindas da indústria da cultura e dos meios de comunicação de massa, tais como livros, jornais, o rádio, a televisão(1). Se admitirmos a crescente dependência dos grupos indígenas em relação ao civilizado, não estaríamos tratando aqui de subsistemas ou part-societies da sociedade brasileira? Em caso afirmativo, tais etnias indigenas exigiriam novos métodos de pesquisa e outras estratégias de reflexão, não-contidas nos modelos antropológicos desenvolvidos no Brasil. Ao meu ver, tais subsistemas só poderiam ser bem estudados se, ao lado das técniças consagradamente antropológicas lobservação participante, estudos de comunidade, elabóração de microssistemas, estruturas de parentesco, sistemas de valores etc.) houver avanços à base de propostas de pesquisa inter e multidisciplinar. Sem isto, seria difícil desenvolver quaisquer cogitações sobre prognósticos, favoráveis ou não, em termos de sua eventual adaptabilidade às novas condições de sobrevivência. As pesquisas inter e multidisciplinares estão em florescimento entre os brazilianists norte-americanos, exímios conhecedores da diversidade de situações humanas que configura o mosaico amazônico, estratégia que, infelizmente, ainda não logrou infiltrar-se nos meios acadêmicos brasileiros.

(1) Atualmente, os índios Bororo reivindicam para si os direitos de venda de imagens e gra. vações de suas tradições culturais, em resposta ao aumento de equipes de civilizados /igados às indústrias da cultura e aos meios de comunicação de massa lgravadoras, filmadoras, equipes de televisão, jornais etc.). 


\section{REFERÊNCIAS BIBLIOGRÁFICAS}

ALMEIDA MELLO, L.I. Projeto de Pesquisa: a geopolitica do Brasil e a Bacia Amazônica. São Paulo, 1987. (Texto datilografado).

BONFIL, G. Do indigenismo da revolução à antropologia crítica. In: JUNQUEIRA, C. \& CARVALHO, E.A., org. Antropologia e Indigenismo na América Latina. São Paulo, Cortez, 1981.

CARDOSO DE OLIVEIRA, R. A sociologia do Brasil Indigena. Rio de Janeiro, Editora Universidade de Brasília/Tempo Brasileiro, 1978.

CLASTRES, P Society against the state. New York, Mole, 1977.

DALLARI, D.A. Minérios, índios e (in)dependência: In: A questão da mineração em Terra Indígena. Cadernos da Comissão Pró-Indio/SP, (4), 1985.

DAVIS, S. Victims of the miracle: development and the indians of Brazil. Cambridge, Cambridge University Press, 1977.

GALVÃO, E. The encounter of tribal and national societies in the Brazilian Amazon. In: MARGOLIS, M.L. \& CARTER, W.E., ed. Brazil: anthropological perspectives: essays in honor of Charles Wagley. New York, Columbia University Press, 1979.

MARTINS, J.S. Capitalismo e tradicionalismo. São Paulo, Pioneira, 1975.

Os Camponeses e a política no Brasil. Petrópolis, Vozes, 1981.

Não há terra para plantar neste verão. Petrópolis, Vozes, 1986.

MURPHY, R. Headhunter's heritage. Berkeley, University of California, 1960.

SAHLINS, M. A cultura e o meio ambiente: o estudo da ecologia cultural. In: Sol Tax, org. Panorama da Antropologia. São Paulo, Fundo de Cultura, 1966.

SANTILLI, M. Projeto calha norte: leitura comentada da exposição de motivos. São Paulo, 1987. (Texto datilografado).

VIERTLER, R.B. Córrego Grande revisitada. Revista da Universidade de São Paulo, (4): 119-42, mar. 1987.

WORLD BANK. Economic development and tribal peoples: human ecologic considerations. Washington, The Office of Environmental Affairs, July. 1981.

\section{FICHA CATALOGRÁFICA}

VIERTLER, R.B. Amazônia Brasileira: preâmbulo a uma discussão antropológica da questão indígena. Revista da Universidade de São Paulo. São Paulo, (6): 98-126, jul./set. 1987. 